\title{
An assessment of factors which motivate consumers to shop online in Lucknow, the capital of Uttar Pradesh
}

Rini Charan and Suprit John Joshi

ABSTRACT : E-commerce has made it easier for small business owners, artists and entrepreneurs to sell online from an online store or website. It is easy for the customers to compare products online than at malls or physical stores and there is a lot of information available online regarding products so why not use this vast information. This study will help the e-tailers to change their course of action, logistics or marketing strategies to attract more customers online and win their trust with lesser complains and increased profit for the firm. Samples were selected by convenient and purposeful sampling from a large number of customers at Lucknow. The sample size was 150 and people were interviewed from various areas of Lucknow to get diversity in the sample. The data was analysed by using percentage method. Out of 150 respondents 138 respondents agree and strongly agree that the main reason for shopping online is that it saves time which represents 92 per cent of respondents. More than 50 per cent respondents (i.e. 74\%) find easy availability of better products (when compared to products offline) a major reason to purchase online. There has been a good number (122 out of 150 respondents) of respondents who consider availability of various colours and sizes of the products online to be a major reason why they prefer to shop online rather than offline. Contrary to the given data out of 150 respondents only 36 consider lower price of online products (as compared to price of same products offline) to be a major determinant of online shopping. Most respondents i.e. 107 do not consider lower price of online products to be a major determinant of online shopping. Around $4 / 5^{\text {th }}$ of respondents which represent 80 per cent consider cash on delivery or easy returns to be a major determinant of online shopping. That concludes that this feature of certain websites attracts the consumers to shop online.

KEY WORDS : Online shopping, Respondents, Price, Websites, COD

HOW TO CITE THIS PAPER : Charan, Rini and Joshi, Suprit John (2018). An assessment of factors which motivate consumers to shop online in Lucknow, the capital of Uttar Pradesh. Res.J. Agric. Eco. \& Stat., 9 (2) : 388-392, DOI : 10.15740/HAS/IRJAES/9.2/388-392. Copyright@ 2018: Hind Agri-Horticultural Society. 